\title{
The relationship between the key sectors in the european union economy and the intra-European Union trade
}

\author{
Martha G. Alatriste-Contreras
}

Correspondence:

marthaalatriste@gmail.com Division de economia, CIDE,

Carretera México-Toluca 3655 Col. Lomas de Santa Fe, 01210 Mexico, D.F., Mexico

\section{严 Springer}

\begin{abstract}
The paper studies the properties of the productive structure of a region and national economies within the region. We use input-output data to calculate and compare input-output linkages and complex network measures of centrality to identify the most important sectors. We found that the most important sectors in each country are also the most important sectors in the European Union as a whole. Moreover, these sectors are the most intra-European Union traded goods and services. Finally, we computed the effect of a sectoral shock and its diffusion throughout the economy. We found that the most central sectors have the best diffusion of the effect of a shock and also a high aggregate impact in the economy. This gives evidence that centrality measures provided additional information that allowed to identified key sectors that have high linkages and good diffusion of effects. Therefore, the computation of centralities provides an alternative method to identify key sectors and formulate economic policies, complementing input-output analysis.
\end{abstract}

Keywords: Intersectoral linkages; Productive structure; Centralities

JEL codes: $C 67 ; O 52 ; \mathrm{L} 14$

\section{Background}

The structure of the interdependencies between sectors determines the aggregate and sectoral impact of sectoral shocks and stimulus. Nevertheless, economic analysis has mainly focused on the aggregate impact without exploring how the effect is asymmetrically distributed among sectors. The aim of the paper is to study the properties of the productive structure of national economies and a region and to identify how this structure determines the different roles and importance of sectors in the economy. We focus on identifying the key sectors that bring the largest impacts on sectoral and aggregate production.

The structure of the economy is defined as the components of the macroeconomic aggregates and the patterns of interactions between them (Thakur 2011). These components are aggregated into economic activities or sectors and are connected through intersectoral linkages. Input-output analysis provides analytical tools to study the intersectoral dependencies and their aggregate impact. Examples of such tools include backward and forward linkages, multipliers, and structural decomposition (McGilvray 1977;

(C) 2015 Alatriste-Contreras et al. Open Access This article is distributed under the terms of the Creative Commons Attribution 4.0 International License (http://creativecommons.org/licenses/by/4.0/), which permits unrestricted use, distribution, and

reproduction in any medium, provided you give appropriate credit to the original author(s) and the source, provide a link to the Creative Commons license, and indicate if changes were made. 
Miller and Blair 2009). Linkage measures are used to identify key sectors in the economy as those that generate above average linkages (Rasmussen 1956). In a development strategy, it is recommendable to stimulate a key sector because it will impact positively on growth (Chenery and Watanabe 1958; Hirschman 1958). After the first introduction of the linkage measures, several changes have been proposed (Jones 1975). Examples of alternative methods to compute linkages include the eigenvector method (Dietzenbacher 1992), the hypothetical extraction method (Dietzenbacher and van der Linden 1997), and complementary measures that capture factors beyond the production system such as environmental or resource factors (Temurshoev and Oosterhaven 2010). Dietzenbacher and Romero (2007) proposed the mean of average propagation lengths that measures the average number of steps it takes for a shock on final demand of sector $i$ to reach sector $j$ and show that the average distance between these two sectors does not depend on whether the backward or forward perspective is adopted. Finally, Humavindu and Stage (2013) introduced the idea of identifying key sectors in the economy not only based on their backward and forward linkages but on the dispersion of those measures to capture how the effects are not evenly distributed. Comparably, the present paper investigates the properties of the structure of the economy and proposes an alternative method to identify key sectors taking into account the diffusion of effects based on the Herfindahl concentration Index and centralities of sectors. In comparison to the input-output literature on the fundamental structure, the analysis in this paper considers all connections between sectors and does not impose a threshold above which the interaction is taken into account and analyzes all channels of the diffusion of a sectoral shock to evaluate the importance of a sector in the economy.

Our analysis is part of an interdisciplinary approach where complex network analysis uses input-output data to study the productive structure of an economy as a network. Literature on this approach has mainly focused on the computation of network measures like centrality of sectors to study the structural properties of the economic system and identify key sectors that play a central role (Blöchl et al. 2011; Garcia-Muniz et al. 2008; McNerney et al. 2012; Reyes 2002; Slater 1978; Xu et al. 2011). Some of the centrality measures applied in network analysis have their equivalent in linkage measures found in input-output literature such as direct linkages and strength measures. Therefore, this paper focuses on exploring centrality measures associated to other structural properties of the economic system like the diffusion of shocks.

We represent the economy as a network, where sectors are nodes and the relationships of supply and demand of inputs are the links connecting them together. This network is a weighted directed graph with self loops. ${ }^{[1]}$ Self loops capture the idea of sectors using their own output as inputs in the production process. The paper analyzes the European Union's (EU) economy as one system and the economy of each country member. Input-output data was obtained from the Eurostat data base for the year 2005 for 22 countries and the EU economy. The method consists on computing input-output linkages and authority and hub centralities of sectors in the network and comparing the most central sectors to the sectors that bring about a high aggregate effect on production when they receive

${ }^{[1]}$ A weighted directed graph is such that the flows from one node to another node are not necessarily the same, so the flow from node $i$ to node $j$ is not the same that the flow from node $j$ to node $i$. For more about weighted directed graphs see (Newman 2010). 
a shock on final demand, while having a good diffusion of the effect across the economy. Results show that the sectors with the highest centralities are the ones that have the best diffusion properties and a high impact on aggregate production. These results have important implications for economic policy design because authority and hub scores identify key sectors in the economy suited for selective promotion when the government is aiming at a high aggregate impact and a wide diffusion of the effect across sectors.

The rest of the paper is organized as follows. Section 2 covers data and methods, where we detailed the database and define the measures we applied. Section 3 presents the results for the European Union and each country member. Section 4 makes a discussion about the results and its implications for the European economy and concludes.

\subsection{Data}

Input-output data provides a natural source of information for representing the economy as a network. This type of data describes the intersectoral dependencies in an economy. However, input-output tables offer as many representations of the economy as sector classifications there are. Nevertheless, having available input-output tables for several countries and regions under one homologous classification represents an advantage to study productive structures together. Therefore, we use input-output data for the European Union under one unique sector classification.

Eurostat provides symmetric input-output tables for the EU as a whole and for each European country in the EU. ${ }^{[2]}$ These tables give information on the intersectoral transactions in million Euros and use the NACE Rev. 1 classification on a second level consisting of divisions. ${ }^{[3]}$ The input-output tables are disaggregated into 59 sectors or economic activities (see Table 1). The most recent year when the EU and most of the countries have an intermediate demand table useful for the analysis is 2005. We left out Bulgaria, Cyprus, Latvia, and Malta that did not have data for that year, leaving the following 22 countries for the analysis: Austria, Belgium, Czech Republic, Denmark, Estonia, Finland, France, Germany, Greece, Hungary, Ireland, Italy, Lithuania, Luxembourg, The Netherlands, Poland, Portugal, Romania, Slovenia, Spain, Sweden, and the UK. Therefore, we have 23 input-output tables, one for each of the 22 European countries and one for the $\mathrm{EU}$ as a whole.

\section{Methods}

Input-output analysis provides analytic tools to study the intersectoral dependencies of an economy. However, these tools do not capture all the properties of the economic system. To overcome this challenge, we complement input-output literature with the application of network measures of centrality to identify key sectors. We start by describing the tools we use to study the properties of the economy and continue to explain how we measure aggregate effects and their diffusion in the system.

\subsection{Structural properties}

We study the properties of the economy using input-output data, where the intermediate demand table contains the flow of resources among sectors. Total output of a sector is

\footnotetext{
${ }^{2]}$ Source: http://epp.eurostat.ec.europa.eu/portal/page/portal/esa95_supply_use_input_tables/data/workbooks ${ }^{[3]}$ NACE Rev. 2. Statistical classification of economic activities in the European Community. Eurostat, Methodologies and Working papers ASSN 1977-0375, p. 27
} 
Table 1 European sectors' classification

\begin{tabular}{|c|c|}
\hline Sector name & $\begin{array}{l}\text { Sector classification } \\
\text { (NACE Rev. 2) }\end{array}$ \\
\hline Products of agriculture hunting and related services & 01 \\
\hline Products of forestry logging and related services & 02 \\
\hline Fish and other fishing products services incidental to fishing & 05 \\
\hline Coal and lignite peat & 10 \\
\hline $\begin{array}{l}\text { Crude petroleum and natural gas services incidental to oil and gas extraction } \\
\text { excluding surveying }\end{array}$ & 11 \\
\hline Uranium and thorium ores & 12 \\
\hline Metal ores & 13 \\
\hline Other mining and quarrying products & 14 \\
\hline Food products and beverages & 15 \\
\hline Tobacco products & 16 \\
\hline Textiles & 17 \\
\hline Wearing apparel and furs & 18 \\
\hline Leather and leather products & 19 \\
\hline \multicolumn{2}{|l|}{ Wood and products of wood and cork (except furniture) articles of straw } \\
\hline and plaiting materials & 20 \\
\hline Pulp paper and paper products & 21 \\
\hline Printed matter and recorded media & 22 \\
\hline Coke refined petroleum products and nuclear fuel & 23 \\
\hline Chemicals chemical products and man-made fibbers & 24 \\
\hline Rubber and plastic products & 25 \\
\hline Other non-metallic mineral products & 26 \\
\hline Basic metals & 27 \\
\hline Fabricated metal products except machinery and equipment & 28 \\
\hline Machinery and equipment n.e.c. & 29 \\
\hline Office machinery and computers & 30 \\
\hline Electrical machinery and apparatus n.e.c. & 31 \\
\hline Radio television and communication equipment and apparatus & 32 \\
\hline Medical precision and optical instruments watches and clocks & 33 \\
\hline Motor vehicles trailers and semi-trailers & 34 \\
\hline Other transport equipment & 35 \\
\hline Furniture other manufactured goods n.e.c. & 36 \\
\hline Recovered secondary raw materials & 37 \\
\hline Electrical energy gas steam and hot water & 40 \\
\hline Collected and purified water distribution services of water & 41 \\
\hline Construction work & 45 \\
\hline \multicolumn{2}{|l|}{ Trade maintenance and repair services of motor vehicles and motorcycles } \\
\hline retail trade services of automotive fuel & 50 \\
\hline Wholesale trade and commission trade services except of motor vehicles & 51 \\
\hline \multicolumn{2}{|l|}{$\begin{array}{l}\text { Retail trade services except of motor vehicles and motorcycles repair services of } \\
\text { personal }\end{array}$} \\
\hline and household goods & 52 \\
\hline Hotel and restaurant services & 55 \\
\hline Land transport and transport via pipeline services & 60 \\
\hline Water transport services & 61 \\
\hline Air transport services & 62 \\
\hline Supporting and auxiliary transport services travel agency services & 63 \\
\hline Post and telecommunication services & 64 \\
\hline Financial intermediation services except insurance and pension funding services & 65 \\
\hline $\begin{array}{l}\text { Insurance and pension funding services except compulsory social security } \\
\text { services }\end{array}$ & 66 \\
\hline Services auxiliary to financial intermediation & 67 \\
\hline Real estate services & 70 \\
\hline
\end{tabular}


Table 1 European sectors' classification (Continued)

\begin{tabular}{lc}
\hline Renting services of machinery and equipment without operator and of personal & 71 \\
and household goods & 72 \\
Computer and related services & 73 \\
Research and development services & 74 \\
Other business services & 75 \\
Public administration and defence services compulsory social security services & 80 \\
Education services & 85 \\
Health and social work services & 90 \\
Sewage and refuse disposal services sanitation and similar services & 91 \\
Membership organisation services n.e.c. & 92 \\
Recreational cultural and sporting services & 93 \\
Other services & 95 \\
Private households with employed persons &
\end{tabular}

expressed as a function of the demand for the different commodities produced in the economy and is defined in vector form as follows:

$$
\mathbf{x}=\mathbf{Z 1}+\mathbf{d}
$$

where $\mathbf{x}$ is the $n \times 1$ column vector of output, $\mathbf{Z}$ is the $n \times n$ interindustry flows matrix, in which $z_{i j}$ represent interindustry sales by sector i to sector $\mathbf{j}, \mathbf{1}$ is a column vector of ones, and $\mathbf{d}$ is the $n \times 1$ column vector of final demand. Final demand is constituted by household consumption, government consumption, exports, and investment. ${ }^{[4]}$

Define the direct input coefficients as the ratio of input supplied by $i$ and bought by $j$ over the output of sector $j$ as $a_{i j}=z_{i j} / x_{j}$, and substitute $\mathbf{Z 1}$ in Eq. 1 for Ax to obtain:

$$
\mathbf{x}=\mathbf{A x}+\mathbf{d}
$$

where $\mathbf{A}$ is the $n \times n$ matrix of direct input coefficients. Direct input coefficients are input per output, thus give a measure of the requirements of a sector to produce. ${ }^{[5]}$

Solving for $\mathrm{x}$ yields:

$$
\mathbf{x}=(\mathbf{I}-\mathbf{A})^{-\mathbf{1}} \mathbf{d}=\mathbf{L} \mathbf{d}
$$

where $\mathbf{L}=(\mathbf{I}-\mathbf{A})^{-1}=\left[l_{i j}\right]$ is an $n \times n$ matrix known as the Leontief inverse or the total requirements matrix.

The structure of the economy captured in the matrix $\mathbf{A}$ implies an organization of sectors. In this organization, some sectors are suppliers of many other sectors while others supply to just a few. Similarly, some sectors demand inputs from several sectors while others are practicably independent. The organization just described defines a hierarchy where the sectors that are better connected to others are at the top and could be considered as more important. To identify the most important or central sectors in the economy, we compute centrality measures used in network analysis. Some measures are equivalent to linkage measures known in input-output analysis. Examples include direct input-output linkages that are equivalent to strength network measures computed using the direct input coefficient matrix. Strength measures count the number of direct connections, and their magnitude, between a node and its immediate neighbors, therefore are local centrality measures. Another example are backward linkages computed with the

\footnotetext{
${ }^{[4]}$ Total output is intermediate demand for inputs plus final demand and is equivalent to total production.
}

${ }^{[5]}$ Leontief (1949), pp.275-278 
eigenvector method that are equivalent to the eigenvector centrality which is the largest eigenvector of the matrix that represents the structure of the system. We will further define these measures in the following section. We propose to complement the analysis using two different measures of centrality that capture the number and quality of the intersectoral connections, in addition to taking into account the diffusion properties of sectors according to their role in the economy: authority and hub scores. Quality refers to the fact that a connection may link a node to an important node or to a peripheral node that is not as important in the system.

\subsubsection{Number and intensity of connections}

The structure of intersectoral dependencies gives rise to a weighted directed graph with self loops (Amaral et al. 2007; Blind and Murphy 1974; Blöchl et al. 2011). This graph is the network representation of the economy where a node represents a sector and a weighted directed edge represents an economic relation between sectors to demand or supply inputs. Self loops capture the idea of a sector using its own product as input and will be of importance when analyzing the concentration of additional resources flowing through the network. The weighted adjacency matrix has entries:

$$
a_{i j} \begin{cases}>0 & \text { if there exits a link between } i \text { and } j \\ =0 & \text { otherwise }\end{cases}
$$

where $a_{i j}$ is the $i j$ th element of the direct input coefficients matrix A. Since the network is weighted and directed we have that $a_{i j} \neq a_{j i}$, and $a_{i i}>0$ when sector $i$ has a self loop of magnitude $a_{i i}$.

In each of the 23 input-output networks there are 59 nodes corresponding to the sector classification defined in the data section. One exception is the French input-output network which has 57 nodes because there are two sectors disconnected from the rest of the economy: uranium and thorium ores, and recovered secondary raw materials. ${ }^{[6]}$

A first structural property of the economy is the density of the network. This measure calculates the number of connections or interactions between sectors relative to the total number of connections that could exists if all nodes were connected (Newman 2010).

A more informative measure of the structure of connections is given by the degree that counts the number of connections that a sector has with its immediate neighbors (Newman 2010). Since it counts the connections only with the immediate neighbors, the degree is a measure of local centrality. According to the direction of the connections a sector has an indegree and an outdegree, which are defined by the following equations:

$$
\begin{aligned}
& d_{i}^{i n}=\sum_{j \neq i} \phi_{j i}=\left(\Phi^{\mathbf{T}}\right)_{i} 1 \\
& d_{i}^{\text {out }}=\sum_{j \neq i} \phi_{i j}=(\Phi)_{i} 1
\end{aligned}
$$

where $d_{i}^{i n}$ is the indegree of node $i, \phi_{j i}$ is an element of the binary or non-weighted adjacency matrix $\Phi$, which is equal to 1 if there exists a link pointing from $j$ to $i$ and zero otherwise, $d_{i}^{\text {out }}$ is the outdegree, and $\mathbf{1}$ is a column vector of ones.

${ }^{[6]}$ France stopped extracting uranium in 2001. Currently, much of the uranium that France uses for its electricity generation comes from Areva in Canada and Niger together with other imports, principally from Australia, Kazakhstan and Russia, mostly under long-term contracts. Beyond this, it is self-sufficient. Source: http://www.world-nuclear.org/ info/inf40.html 
In the input-output network context, indegree is interpreted as the number of direct connections that a sector has with its input suppliers. Outdegree measures the number of direct connections between a sector and its input buyers.

As mentioned in the previous section, network analysis provides a measure to evaluate the number and magnitude of the connections between two nodes: strength. According to the direction of the connection, a node can have instrength and outstrength. These are calculated as the row and column sum of the weighted adjacency matrix A:

$$
\begin{gathered}
s_{i}^{\text {in }}=\sum_{j \neq i} a_{j i}=\left(\mathbf{A}^{\mathbf{T}}\right)_{i} 1 \\
s_{i}^{\text {out }}=\sum_{j \neq i} a_{i j}=(\mathbf{A})_{i} 1
\end{gathered}
$$

where $s_{i}^{i n}$ is the instrength of node $i, a_{j i}$ is an element of the adjacency matrix $A$ and represents the strength or magnitude of the link pointing from $j$ towards $i, s_{i}^{\text {out }}$ is the outstrength, and $a_{i j}$ is the magnitude of the link pointing outwards from node $i$ to node $j$.

In the input-output context, strength measures are equivalent to the direct backward and forward linkages, calculated as the column and row sum of the direct input coefficients matrix.

\subsubsection{Authority and hub scores}

Authority and hub scores are a generalization of the eigenvector centrality for directed networks. This centrality acknowledges that not all connections are equal because nodes connected to more important nodes are more important themselves (Borgatti 2005). The eigenvector centrality gives each node a score that depends both on the number and the quality of its connections, where a node with a smaller number of high-quality links may outrank one with a larger number of mediocre links (Newman 2010). ${ }^{[7]}$ The quality of their connections takes into account two things, the strength of the connection with other nodes and the fact that a node is connected to other important nodes.

According to the directionality of the connection of a node, we can compute the right and the left largest eigenvector of the adjacency matrix to define the importance of a node in terms of other nodes pointing towards that node, and the importance of a node in terms of other nodes being pointed by the node, respectively. As mentioned before, the right eigenvector centrality is equivalent to the backward linkages computed with the eigenvector method described in Dietzenbacher (1992) where linkages are the right principal eigenvector of the direct input coefficients matrix. However, eigenvector centrality for directed networks, such as the input-output network, has problems for computing the centrality of nodes in and outside strongly connected components. ${ }^{[8]}$ Nodes connected to nodes with zero centrality will receive scores of zero (Newman 2010). In the input-output context, sectors that are highly independent from other sectors' inputs would have a centrality of zero even if those sectors supply their product to other sectors as input. To get around this problem, Kleinberg (1999) proposed to compute authority and hub scores for directed networks.

[7] Eigenvector centrality was first proposed in Bonacich (1987) as a power measure in social networks. In Borgatti (2005) eigenvector centrality counts the number of walks of all lengths, weighted inversely by length, which emanate from a node, so it can be interpreted as an accessibility index.

${ }^{[8]}$ A strongly connected component is a maximal subset of nodes such that there is a directed path in both direcitons between every pair in the subset (Newman (2010), p. 144). 
The authority and hub scores are based on a mutually reinforcing relationship where good authorities are pointed by good hubs and good hubs point to good authorities (Kleinberg 1999). ${ }^{[9]}$ We thus have a circular definition of hubs and authorities. This is turned into an iterative computation, where the algorithm assigns a hub score $y_{i}$ and an authority score $x_{i}$ to each node, which is initially $x=y=1$. The core of the process is a pair of updates to the hub and authority scores of all nodes (Kleinberg 1999). For their computation, the authority centrality of a node is proportional to the sum of the hub centralities of the nodes that point to it, and the hub centrality of a node is proportional to the authority centrality of the nodes it points to (Newman 2010). The scores are successively computed as follows:

$$
\begin{aligned}
& x_{i}^{(k)}=\sum_{j: e_{j i} \in E} y_{j}^{k-1} \\
& y_{i}^{(k)}=\sum_{j: e_{i j} \in E} x_{j}^{k}
\end{aligned}
$$

for $k=1,2,3, \ldots$, where $E$ is the set of all directed edges on the graph and $e_{i j}$ represents the directed edge between node $i$ to node $j$.

The equations defining the scores in each iteration can be written in matrix form using the adjacency matrix of the directed graph. In the matrix notation, Eqs. 8 and 9 take the following forms:

$$
\begin{aligned}
& x^{(k)}=A^{T} y^{(k-1)} \\
& y^{(k)}=A x^{(k)}
\end{aligned}
$$

The iterative algorithm updates Eqs. 10 and 11 until convergence, where in each iteration $k=k+1$.

This equations can be simplified by substituting the rights-hand side of the equations into the left-hand side to obtain:

$$
\begin{aligned}
& x^{(k)}=A^{T} A x^{(k-1)} \\
& y^{(k)}=A A^{T} y^{(k-1)}
\end{aligned}
$$

These two equations define the iterative power method for computing the dominant eigenvector for the matrices $A^{T} A$ and $A A^{T}$ (Langville and Meyer 2005). $A^{T} A$ and $A A^{T}$ are symmetric positive semidefinite matrices. Computing the authority scores vector and the hub scores vector can be viewed as finding dominant right-hand eigenvectors of $A^{T} A$ and $A A^{T}$.

As in the case for eigenvector centrality, the centralities are given by the eigenvector corresponding to the largest eigenvalue. The authority scores are characterized by Eq. 14, and hub scores are defined by Eq. 15 below (Kleinberg 1999).

$$
\begin{aligned}
& \mathbf{X}=\left(\mathbf{I}-\lambda \mathbf{A}^{\mathbf{T}} \mathbf{A}\right)^{-\mathbf{1}} \mathbf{1} \\
& \mathbf{Y}=\left(\mathbf{I}-\lambda \mathbf{A} \mathbf{A}^{\mathbf{T}}\right)^{-\mathbf{1}} \mathbf{1}
\end{aligned}
$$

[9] Authority and hub scores were originally applied to study the link structure of web pages through the HITS (Hypertext Induced Topic Selection) algorithm. In that context, authorities are the most prominent sources of primary content and hubs assemble high-quality guides and resource lists directing the users of web pages to recommended authorities (Kleinberg 1999). 
To illustrate the relevance of these scores in the input-output network, we develop the concepts in the context. First suppose production of sector $j$ increases due to a shock on final demand. This initiates two chains of effects. On the one hand, sector $j$ increases its demand for inputs. This demand is matched by an increase in the supply of inputs of $j$ 's suppliers. In order to be able to increase supply of inputs, $j$ 's suppliers had to increase production, which in turn, means an increase in demand of inputs, including the output of sector $j$, and so on. On the other hand, other chain of effects starts because there is more output available to be used as inputs after sector $j$ increased it demand. This means that sector $j$ increases its supply of inputs for other sectors. With more inputs available, the other sectors purchase more inputs and increase production. This increase in production, in turn, increases the supply of inputs, and so on.

These chains of effects are happening simultaneously in the economy, where the effects on supply feedback to the demand of inputs and vice versa. This is captured on the circular and mutually reinforcing relationship between authority and hub scores described before where backward linkages and forward linkages are appropriately weighted and may channel feedback effects. Authority and hub scores provide a ranking of sectors in the economy that have the most important role in these chains of effects both directly and indirectly. A sector with a high authority score is such that it not only generates high effects on the demand of inputs, but that it is connected to a sector or sectors that have high hub scores and, thus, generate high effects on the supply of inputs. Therefore a good authority can start chains of effects on both the supply and demand of inputs. The same holds for a good hub, starting with the chain of effects on the supply of inputs. However, the scores are not computing the cumulative magnitude of the effect. Therefore, the scores do not have any interpretation in the sense of a multiplier. Instead, they provide an informative ranking of sectors according to their participation in many production chains.

\subsection{Aggregate impact and diffusion of resources}

We relate the ranking provided by global centralities to the diffusion properties of sectors using the idea that the effect of a shock on final demand has an effect on sectoral and aggregate production.

We can compute total production of all individual sectors as a function of final demand and the magnitudes of the input coefficients following Eq. 3. The impact of a sector $i$ on aggregate output is evaluated as the change in output of sectors needed to compensate a change in final demand of sector $i$. The change in output is defined as follows:

$$
\Delta x=x^{1}-x^{0}=L\left(d^{1}-d^{0}\right)=L \Delta d
$$

where $\Delta$ means difference or change, $\mathbf{x}$ is the output vector, $\mathbf{L}$ is the Leontief matrix, and d is the final demand vector.

Equivalently,

$$
\Delta \mathbf{x}=\mathbf{L} * f, f=\Delta d
$$

where the symbol $*$ means multiplication.

We normalize the effect by the size of the shock to be able to compare across sectors as follows:

$$
\Delta \mathbf{x} / \mathbf{f}=\left(\mathbf{x}^{1}-\mathbf{x}^{\mathbf{0}}\right) / \mathbf{f}=\mathbf{L}
$$

where the symbol / means division. 
Equation 18 implies that the aggregate impact of sector $i$ would be determined by the $i$ th column sum of the Leontief matrix, $\mathbf{L}$, as if the the shock was equal to 1 for all sectors (a unit increase on final demand). ${ }^{[10]}$

With the information contained in the Leontief inverse matrix, we compute a measure of the diffusion properties of a sector based on the Herfindahl concentration index (Herfindahl 1950). This index for the input-output network is defined as follows:

$$
H_{i}=\sum_{j=1}^{n} s_{j}^{2}=\sum_{j=1}^{n}\left(l_{j i} / \sum_{j=1}^{n} l_{j i}\right)^{2}
$$

where $s_{i}$ is the fraction of the effect on production of a shock on final demand that is absorbed by sector $\mathrm{i}, l_{j i}$ is the $j i$ th element of the Leontief inverse, and $n$ is the number of sectors in the economy. To capture the diffusion properties of sectors, we computed $D_{i}=1-H_{i}$ for each sector, where a high $D_{i}$ means good diffusion properties or low concentration of the effect. The diffusion measure is defined as follows:

$$
D_{i}=1-\left[\sum_{j=1}^{n}\left(l_{j i} / \sum_{j=1}^{n} l_{j i}\right)^{2}\right]
$$

\section{Results}

We start reporting our results with the properties of the productive structures of the EU and European countries. We then continue with the identification of key sectors according to centrality measures. We compare key sectors to the sectors with the highest input-output linkages in both geographical scales. Finally, we report the relation between the properties and key sectors of European economies to the structure of intra-EU trade.

\subsection{The properties of the productive structure of the EU Economy}

The biggest sectors in terms of production in the EU's economy in 2005 were as follows: construction work, public administration and defense services, and compulsory social security services, and renting services of machinery and equipment. These sectors are followed in size by sewage and refuse disposal services sanitation and similar services, wholesale trade, education services, and food products and beverages.

The density of the EU's input-output network was 0.95 , a high value that reflects a high connectivity of the economic system where sectors are highly dependent on almost all other sectors. In the year of study, the EU's economy had a highly positively skewed distribution of link weights, where weak links amount to $96 \%$ of all link (see Table 2). The densities of each European country range from high values like UK, France, Germany, and Hungary, which have densities of around 0.7 or above, to low values like Estonia and Lithuania which have densities of around 0.4 and Luxembourg with a density of 0.24 , the lowest in the sample.

The distributions for the indegree and outdegree of sectors in the EU are highly negatively skewed, showing that most of the sectors in the economy have many connections with other sectors (see Figs. 1 and 2). In particular, most of the values of the outdegrees are concentrated on the highest values. This means that there are sectors that supply inputs to many or all other sectors in the economy so they are general suppliers.

${ }^{[10]}$ The column sum of the $\boldsymbol{L}$ matrix is the output multiplier defined in standard input-output analysis (Miller and Blair 2009) 
Table 2 Density of the input-output network in each country

\begin{tabular}{lc}
\hline Countries & Density \\
\hline European Union & 0.95 \\
Austria & 0.61 \\
Belgium & 0.59 \\
Czech Republic & 0.57 \\
Denmark & 0.67 \\
Estonia & 0.38 \\
Finland & 0.64 \\
France & 0.72 \\
Germany & 0.69 \\
Greece & 0.49 \\
Hungary & 0.72 \\
Ireland & 0.58 \\
Italy & 0.58 \\
Lithuania & 0.40 \\
Luxembourg & 0.24 \\
Netherlands & 0.64 \\
Poland & 0.69 \\
Portugal & 0.55 \\
Romania & 0.53 \\
Slovenia & 0.45 \\
Spain & 0.69 \\
Sweden & 0.59 \\
UK & 0.76 \\
\hline
\end{tabular}

On the contrary to the distributions observed for the degree values, the distribution of the instrength and outstrength of sectors in the EU's economy are positively skewed. Specifically, the distribution of instrength concentrates the mass of values in low strengths. On the other hand, the outstrength distribution showed a highly positively skewed distribution, concentrating the values on very low and low strengths (see Figs. 3 and 4).

As shown on the recent analysis in Alatriste-Contreras and Fagiolo G (2014), each European economy at this level of aggregation is characterized by negatively skewed degree distributions and positively skewed strengths distributions. This property points to the fact that each of the national economies have many connections but that most of these connections are very weak, displaying a low strength, especially for the connection between input suppliers and their buyers.

\subsection{The most important sectors in the EU}

The computation of authority and hub scores revealed the existence of only a few very important sectors in the regional and national economies in terms of their global centrality. The distributions for the authority and hub scores are highly skewed to the right, where most of the sectors have low scores and only a few have very high scores (see Figs. 5 and 6).

The most central sectors are those sectors that have the highest scores. In Table 3, we can observe that according to both authority and hub scores, the top ranked sectors of the EU are Uranium and thorium ores, electrical energy, gas, steam and hot water, other business services, construction work, wholesale, and chemicals. 


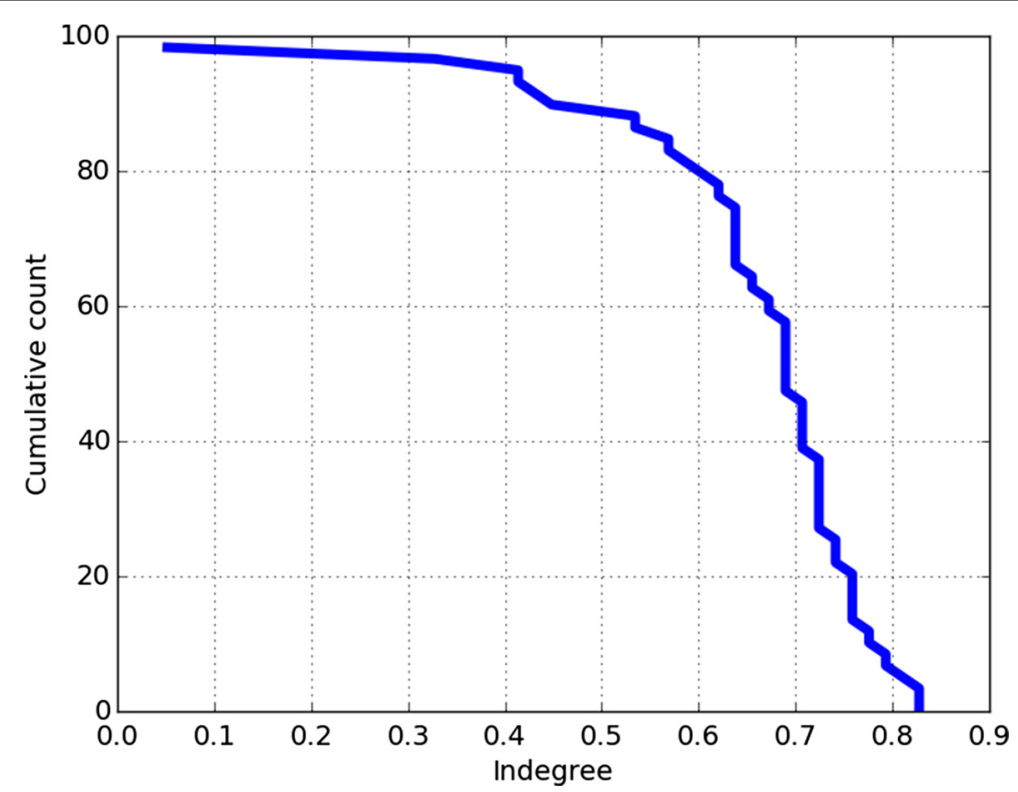

Fig. 1 Indegree distribution

Comparing the most important sectors in the European Union as a whole with the most important sector in each country, we observed the following. From the $22 \mathrm{EU}$ countries, 19 of them had the sector other business services as one of the best authorities and hubs; exceptions are Lithuania, Romania, and Sweden. Other common important sectors are wholesale as one of the best authorities and one of the best hubs in 18 countries, construction as one of the best authorities in 14 countries and one of the best hubs in 21 countries, food and beverages as one of the best authorities in 8 countries and one of the best hubs in 16 countries, real-estate as one of the best authorities in 9 countries and one of the best

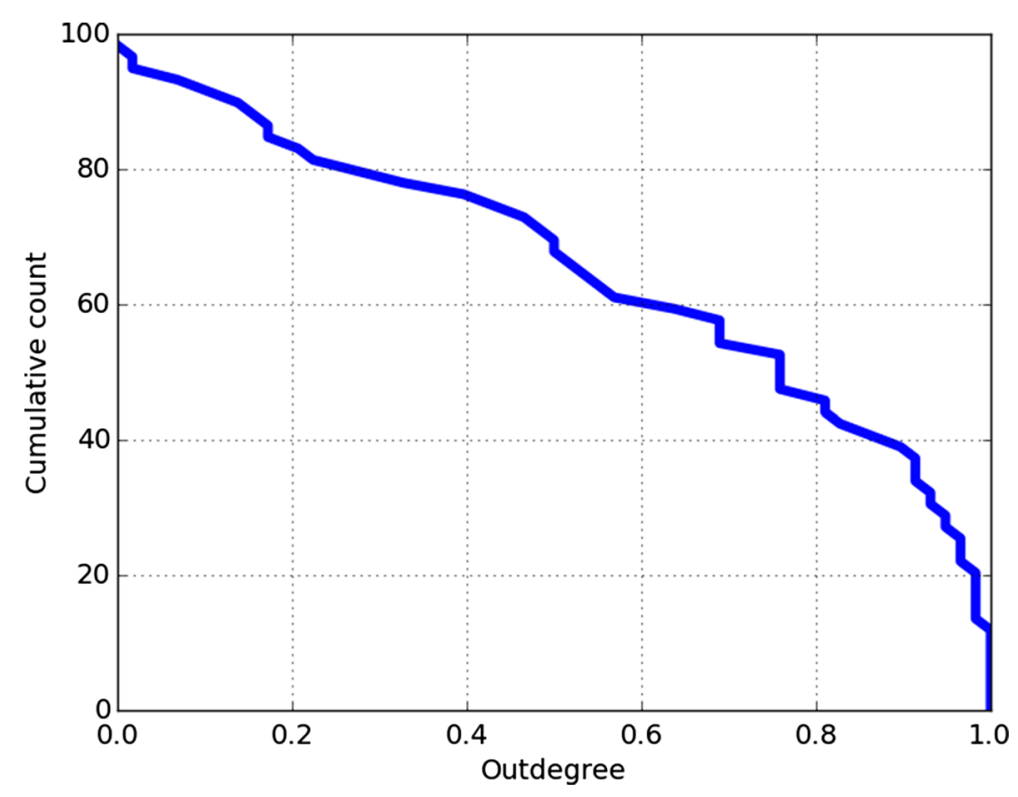

Fig. 2 Outdegree distributions 


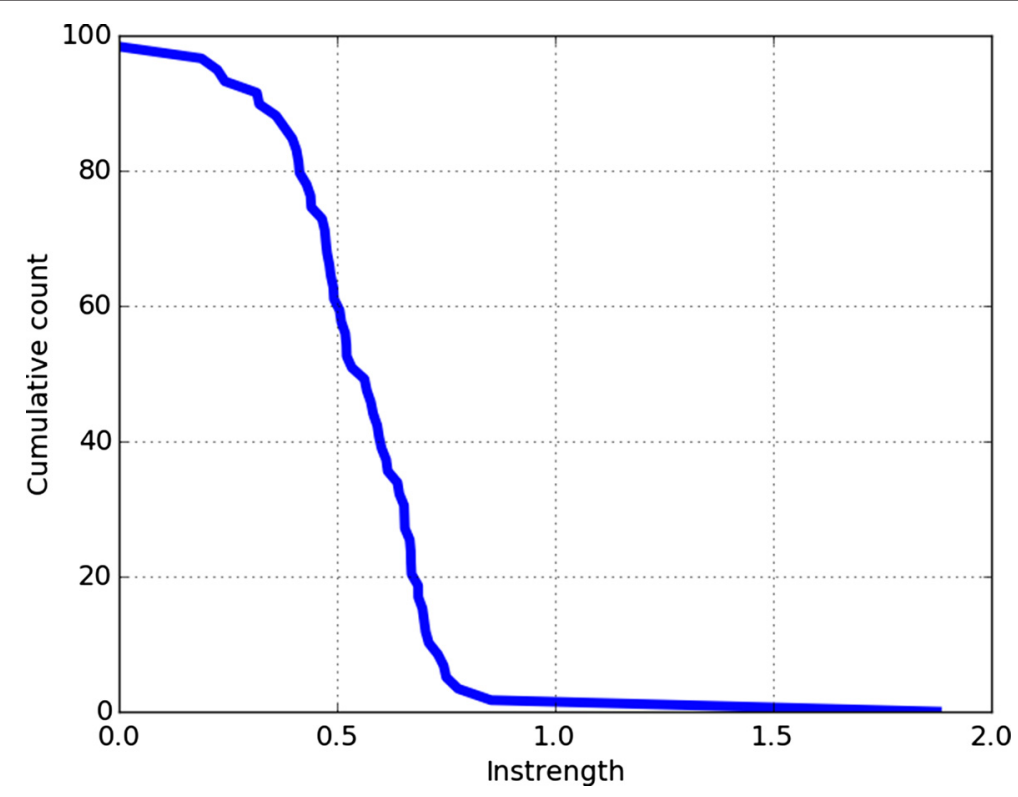

Fig. 3 Instrength distribution

hubs in 14, and chemicals as one of the best authorities in 9 countries and one of the best hubs in 10 (see Table 4). Other common important sectors are electrical energy, natural gas, financial intermediaries, basic metals, and machinery and equipment.

Similarly, the sector supporting and auxiliary transportation services, was a good authority in Belgium, Czech Republic, Germany, Sweden, United Kingdom, Denmark, Estonia, Finland, France, and Lithuania. From these ten countries, in five of them, together

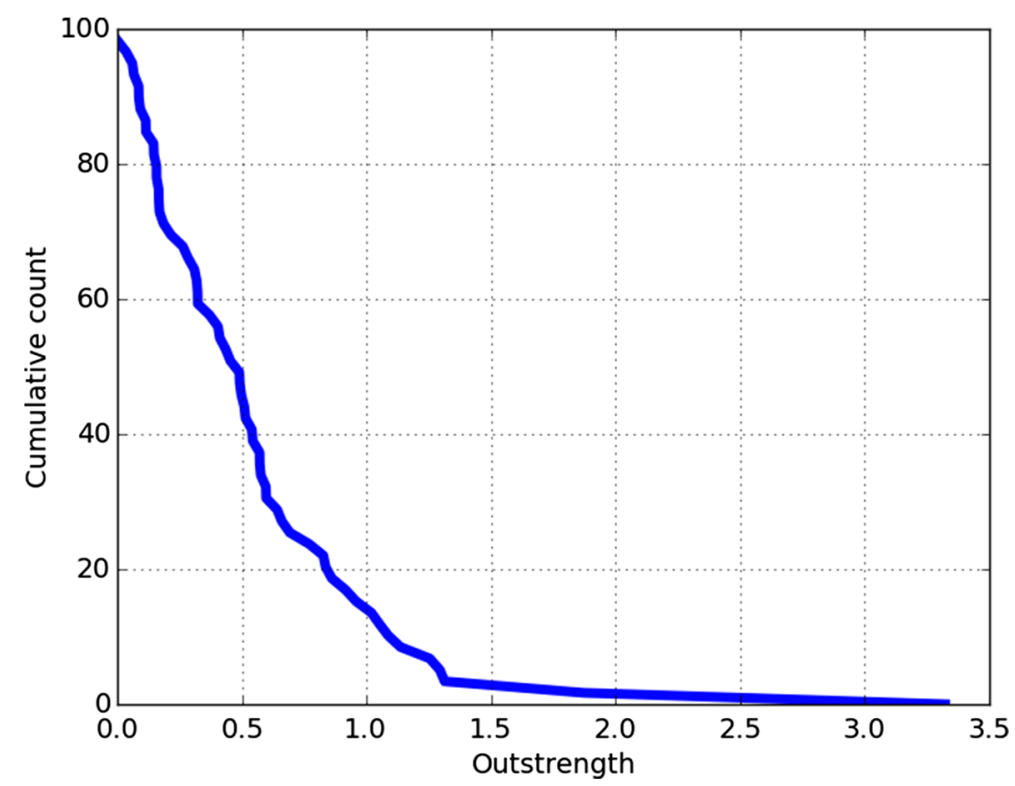

Fig. 4 Outstrength distribution 


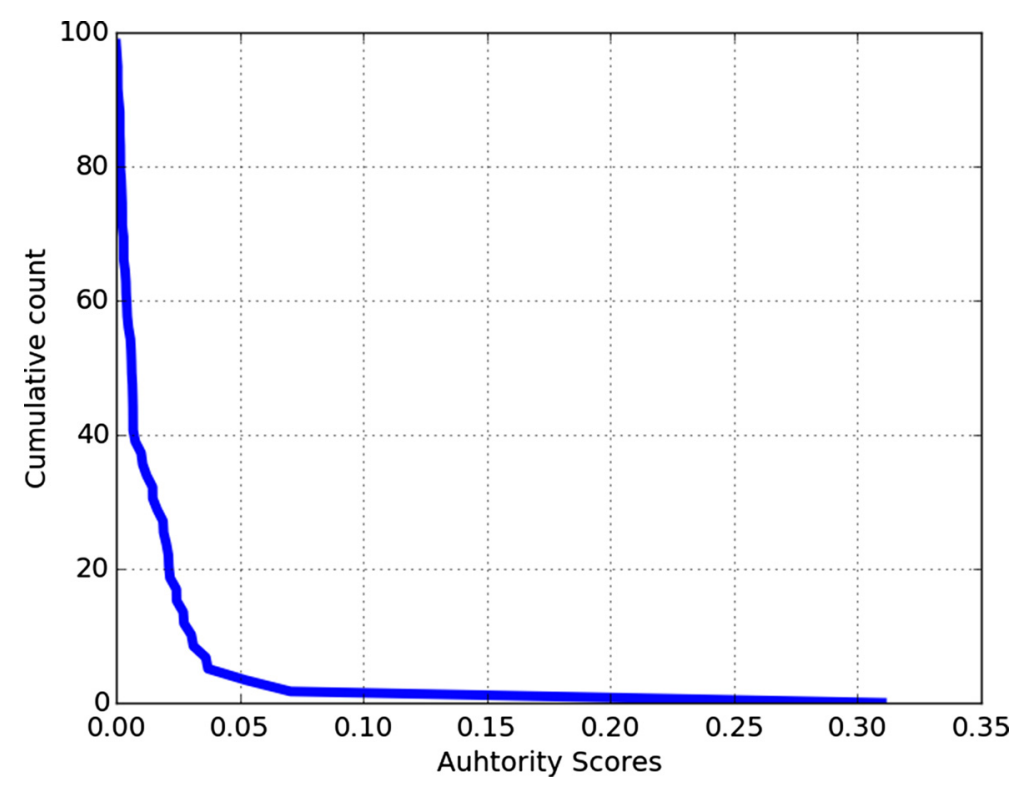

Fig. 5 Authority scores distribution, European Union

with Ireland and Netherlands, it was a good hub as well. At the EU as a whole, this sector took the seventh position on the list of top ten best authorities and had high forward linkages.

We can observe that the most common most important sectors in European countries are the most important sectors in the EU's economy as a whole (see Tables 3 and 4).

In order to observe the differences and similarities between the ranking of sectors provided by authority and hub scores and the ranking of key sectors obtained through the

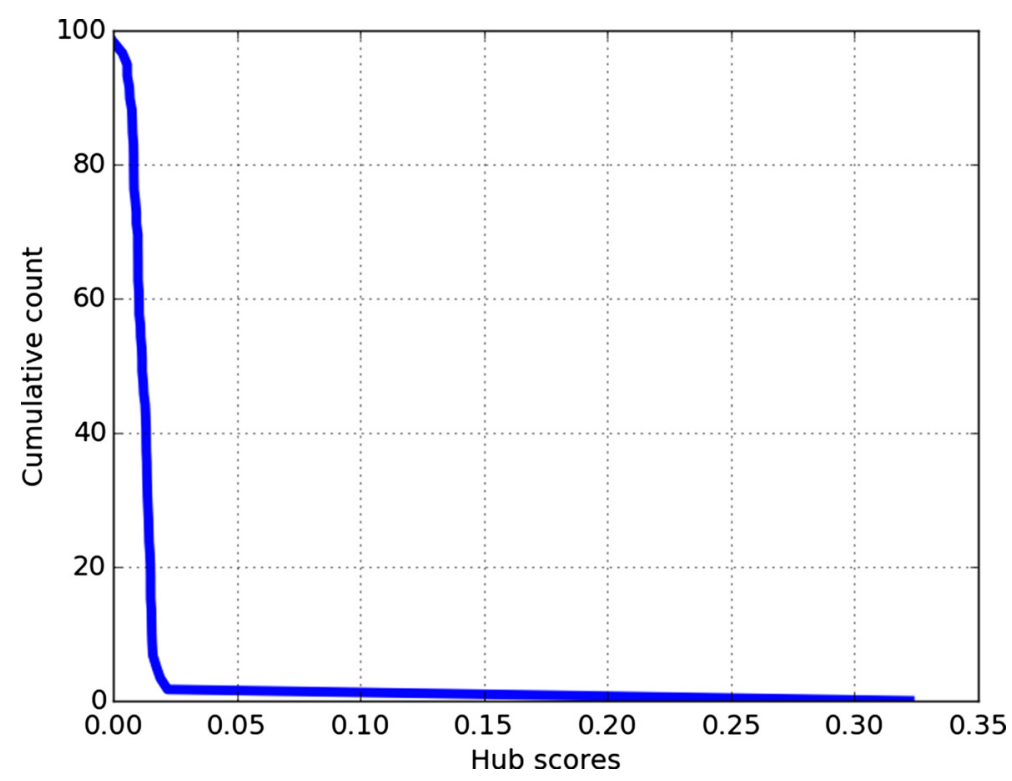

Fig. 6 Hub scores distribution, European Union 
Table 3 Key sectors in the EU according to global centralities

\begin{tabular}{lll}
\hline Ranking & Authority scores & Hub scores \\
\hline 1 & Uranium and thorium ores & Uranium and thorium ores \\
2 & Electrical energy & Electrical energy \\
3 & Other business services & Chemicals \\
4 & Wholesale & Rubber and plastic products \\
5 & Construction & Construction \\
6 & Chemicals & Wood \\
7 & Supporting and auxiliary transport services & Basic metals \\
8 & Fabricated metal products & Other non-metallic mineral products \\
9 & Land transport & Machinery and equipment \\
10 & Coke, refined petroleum, and nuclear fuel & Coke, refined petroleum, and nuclear fuel \\
\hline
\end{tabular}

computation of input-output linkages, we computed the Spearman correlation coefficient between total backward linkages and hub scores, and between total forward linkages and authority scores for each of the 23 economies. ${ }^{[11]}$ The coefficients for the European Union where 0.75 and 0.97 , both high and positive. However, when we computed the coefficients for each country in the EU, we found that the coefficients became much smaller ranging from 0.001 to 0.43 between hub scores and backward linkages, and ranging from 0.008 to 0.3 between authority scores and forward linkages. This highlights a property of all complex systems, which indicated that we cannot induce the behavior or the properties of the whole, the EU, from the behavior or properties of an individual part, each European country. The integrated economy of the EU implies a high connectivity which has a direct impact on the scores of sectors. A high connectivity will bring higher scores. Since each of the EU countries have lower connectivity, their scores are accordingly lower and change according to each national input-output structure. Nevertheless, in all geographical scales, authority and hub scores are correlated to input-output linkages and capture the hierarchical structure of sectors in the economy. We will argue that they capture the information provided by linkage measures but they also provide additional information related to the diffusion properties. This complements the analysis of key sectors, specially at the country level, where the lower connectivity allowed us to have a deeper understanding of the organization of sectors in the economy. We will show the diffusion properties of sectors and their relation to the centrality scores in the next section.

\subsection{Aggregate impact and diffusion of resources}

Sectors were classified according to the highest aggregate impact on production and with respect to the widest diffusion of resources. This classification was then compared to the ranking of the most central sectors in the economy. The top ten sectors with the highest impact on aggregate production in the EU are, in order of magnitude, uranium and thorium ores, motor vehicles, basic metals, office machinery and computers, other transport equipment, recovered secondary raw materials, leather and leather products, food products and beverages, radio television and communication equipment, and coke refined petroleum products and nuclear fuel.

\footnotetext{
[11] We computed the spearman correlation coefficient because it does not impose that the data is normally distributed. This is important because we found that input-output linkages and authority and hub scores are highly skewed distributed.
} 
Table 4 Key sectors according to global centralities in European countries

\begin{tabular}{|c|c|c|}
\hline Countries & Authorities & Hubs \\
\hline Austria & $\begin{array}{l}\text { Other business services, electrical energy, construction, real-estate, and } \\
\text { wholesale }\end{array}$ & $\begin{array}{l}\text { Other business services, electrical energy, construction, real-estate, and } \\
\text { wholesale }\end{array}$ \\
\hline Belgium & $\begin{array}{l}\text { Other business services, chemicals, construction, wholesale, and supporting and } \\
\text { auxiliary transport services }\end{array}$ & $\begin{array}{l}\text { Other business services, wholesale, chemicals, construction, and food and } \\
\text { beverages }\end{array}$ \\
\hline Czech Republic & $\begin{array}{l}\text { Construction, other business services, other non-metallic mineral products, } \\
\text { wholesale, and basic metals }\end{array}$ & $\begin{array}{l}\text { Construction, other business services, real-estate, motor vehicles, and public } \\
\text { administration }\end{array}$ \\
\hline Denmark & $\begin{array}{l}\text { Supporting and auxiliary transport services, coke refined petroleum, other } \\
\text { business services, land transport, and financial intermediaries }\end{array}$ & Water transport, wholesale, air transport, land transport, and construction \\
\hline Estonia & $\begin{array}{l}\text { Radio, television and communication, electrical machinery, other business } \\
\text { services, supporting and auxiliary transport services, and land transport }\end{array}$ & $\begin{array}{l}\text { Radio, television and communication, electrical machinery, construction, } \\
\text { supporting and auxiliary transport services, and wholesale }\end{array}$ \\
\hline Finland & $\begin{array}{l}\text { Radio, television and communication, other business services, wholesale, } \\
\text { machinery and equipment, and construction }\end{array}$ & $\begin{array}{l}\text { Radio, television and communication, construction, machinery and equipment, } \\
\text { paper, and wholesale }\end{array}$ \\
\hline France & $\begin{array}{l}\text { Other business services, financial intermediaries, real-estate, wholesale, and } \\
\text { construction }\end{array}$ & $\begin{array}{l}\text { Other business services, wholesale, construction, food and beverages, and } \\
\text { real-estate }\end{array}$ \\
\hline Germany & $\begin{array}{l}\text { Motor vehicles trailers and semi-trailers, other business services, fabricated metal } \\
\text { products, basic metals, and real-estate }\end{array}$ & $\begin{array}{l}\text { Motor vehicles trailers and semi-trailers, other business services, machinery and } \\
\text { equipment, construction, and chemicals }\end{array}$ \\
\hline Greece & $\begin{array}{l}\text { Agriculture, crude petroleum and natural gas, wholesale, retail, and food and } \\
\text { beverages }\end{array}$ & $\begin{array}{l}\text { Food and beverages, construction, coke refined petroleum, hotels and } \\
\text { restaurants, and agriculture }\end{array}$ \\
\hline Hungary & $\begin{array}{l}\text { Radio, television and communication, electrical machinery, motor vehicles, other } \\
\text { business services, and office machinery }\end{array}$ & $\begin{array}{l}\text { Radio, television and communication, motor vehicles, office machinery, electrical } \\
\text { machinery, and construction }\end{array}$ \\
\hline Ireland & Other business services, chemicals, wholesale, $R \& D$, and construction & $\begin{array}{l}\text { Chemicals, other business services, computer and related services, printed matter } \\
\text { and recorded media, and food and beverages }\end{array}$ \\
\hline Italy & Other business services, chemicals, wholesale, $R \& D$, and construction & $\begin{array}{l}\text { Chemicals, other business services, computer and related services, printed matter } \\
\text { and recorded media, and food and beverages }\end{array}$ \\
\hline Lithuania & $\begin{array}{l}\text { Crude petroleum and natural gas, electrical energy, wholesale, chemicals, and } \\
\text { land transport }\end{array}$ & $\begin{array}{l}\text { Chemicals, electrical energy, rubber and plastic, food and beverages, and } \\
\text { construction }\end{array}$ \\
\hline Luxembourg & $\begin{array}{l}\text { Services auxiliary to financial intermediaries, financial intermediaries, other } \\
\text { business services, post and telecommunications, and computer and related } \\
\text { services }\end{array}$ & $\begin{array}{l}\text { Financial intermediaries, services auxiliary to financial intermediaries, insurance } \\
\text { and pension funding, construction, and wholesale }\end{array}$ \\
\hline Netherlands & $\begin{array}{l}\text { Other business services, construction, chemicals, crude petroleum and natural } \\
\text { gas, and food and beverages }\end{array}$ & $\begin{array}{l}\text { Other business services, construction, chemicals, wholesale, and food and } \\
\text { beverages }\end{array}$ \\
\hline
\end{tabular}


Table 4 Key sectors according to global centralities in European countries (Continued)

\begin{tabular}{|c|c|c|}
\hline Poland & $\begin{array}{l}\text { Agriculture, food and beverages, wholesale, other business services, and } \\
\text { construction }\end{array}$ & $\begin{array}{l}\text { Food and beverages, agriculture, construction, wholesale, and other business } \\
\text { services }\end{array}$ \\
\hline Portugal & $\begin{array}{l}\text { Construction, other non-metallic mineral products, other business services, } \\
\text { fabricated metal product, and wholesale }\end{array}$ & $\begin{array}{l}\text { Construction, other business services, real-estate, wholesale, and food and } \\
\text { beverages }\end{array}$ \\
\hline Romania & Agriculture, food and beverages, retail, electrical energy, and wholesale & $\begin{array}{l}\text { Agriculture, food and beverages, construction, wholesale, and hotels and } \\
\text { restaurants }\end{array}$ \\
\hline Slovenia & $\begin{array}{l}\text { Construction, other non-metallic mineral products, fabricated metal products, } \\
\text { other business services, and basic metals }\end{array}$ & $\begin{array}{l}\text { Construction, other business services, machinery and equipment, fabricated } \\
\text { metal products, and wholesale }\end{array}$ \\
\hline Spain & $\begin{array}{l}\text { Construction, other non-metallic mineral products, fabricated metal products, } \\
\text { wholesale, and other business services }\end{array}$ & $\begin{array}{l}\text { Construction, real-estate, food and beverages, hotels and restaurants, and other } \\
\text { business services }\end{array}$ \\
\hline Sweden & $\begin{array}{l}R \& D \text {, real-estate, motor vehicles, trade maintenance and repair services of motor } \\
\text { vehicles, and supporting and auxiliary transport services }\end{array}$ & $\begin{array}{l}R \& D \text {, trade maintenance and repair services of motor vehicles, motor vehicles, } \\
\text { real-estate, and electrical machinery }\end{array}$ \\
\hline UK & $\begin{array}{l}\text { Other business services, construction, real-estate, computer and related services, } \\
\text { and post and telecommunications }\end{array}$ & $\begin{array}{l}\text { Construction, other business services, real-estate, public administration, and } \\
\text { wholesale }\end{array}$ \\
\hline
\end{tabular}


Table 5 Most affected sectors. Some examples in the European Union

\begin{tabular}{|c|c|c|c|c|c|c|c|}
\hline Ranking & $\begin{array}{l}\text { Uranium and thorium } \\
\text { ores }\end{array}$ & Motor vehicles & $\begin{array}{l}\text { Recovered secondary } \\
\text { raw materials }\end{array}$ & Basic metals & $\begin{array}{l}\text { Private household with } \\
\text { employed persons }\end{array}$ & Furniture & Rubber and plastics \\
\hline 1 & $\begin{array}{l}\text { Uranium and thorium } \\
\text { ores (5) }\end{array}$ & $\begin{array}{l}\text { Motor vehicles } \\
\text { (27) }\end{array}$ & $\begin{array}{l}\text { Recovered secondary } \\
\text { raw materials }(30)\end{array}$ & Basic metals (20) & $\begin{array}{l}\text { Private } \mathrm{HH} \text { with employed } \\
\text { persons (58) }\end{array}$ & Furniture (29) & Rubber and plastics (18) \\
\hline 2 & $\begin{array}{l}\text { Electrical energy gas } \\
\text { stream and hot water } \\
\text { (31) }\end{array}$ & $\begin{array}{l}\text { Other business } \\
\text { services }(50)\end{array}$ & Basic metals (20) & $\begin{array}{l}\text { Other business } \\
\text { services }(50)\end{array}$ & $\begin{array}{l}\text { Financial intermediaries } \\
\text { (43) }\end{array}$ & $\begin{array}{l}\text { Other business } \\
\text { services (50) }\end{array}$ & Chemicals (17) \\
\hline 3 & $\begin{array}{l}\text { Other business } \\
\text { services }(50)\end{array}$ & Basic metals (20) & $\begin{array}{l}\text { Other business } \\
\text { services }(50)\end{array}$ & $\begin{array}{l}\text { Other business } \\
\text { services (50) }\end{array}$ & & Wood (13) & $\begin{array}{l}\text { Other business } \\
\text { services }(50)\end{array}$ \\
\hline 4 & Construction (33) & $\begin{array}{l}\text { Fabricated metal } \\
\text { products (21) }\end{array}$ & $\begin{array}{l}\text { Fabricated metal } \\
\text { products }(21)\end{array}$ & Wholesale (35) & Wholesale (35) & Wholesale (35) & \\
\hline
\end{tabular}


On a second step, sectors were classified according to their diffusion properties. A sector with good diffusion properties is such that it distributes the effects of a shock to a wider set of other sectors as oppose to concentrate the effect into itself or just a few others. The relationship between aggregate effect on production and diffusion of the effect in the EU is positive but not linear (see Fig. 7). The upper right corner of Fig. 7 displays the sectors with high aggregate effect and good diffusion properties: motor vehicles, basic metals, uranium and thorium ores, machinery and equipment, among others. These sectors correspond to the sectors identified before as key sectors in the economy and to sectors that are connected to other important sectors. For example, most of these sectors are connected to other business services, construction and electrical energy, all of which are good hubs. In Fig. 8, we analyze some particular cases that are worthy of a detailed analysis.

Figure 8 shows the detailed distribution of the effect on production of a shock on final demand according to different targets. The sectors' number (id) is on the $\mathrm{x}$-axis, the magnitude of the effect received by each sector is on the y-axis, and the different colors of the lines represent distinct targets. The distributions vary in shape according to the target and have peaks in different locations where a high portion of the effect is concentrated like the cyan-star line. Distinctively, the red-pentagons line and the black-squares line show more evenly distributed effects. These results show that the sectors that had the widest distribution of the effect, displaying low concentrations of the effect, are the ones with the highest global centralities Table 5. Therefore, global centralities capture the diffusion properties of sectors, that is, their capability to spillover resources (effects) to a wider part of the economy.

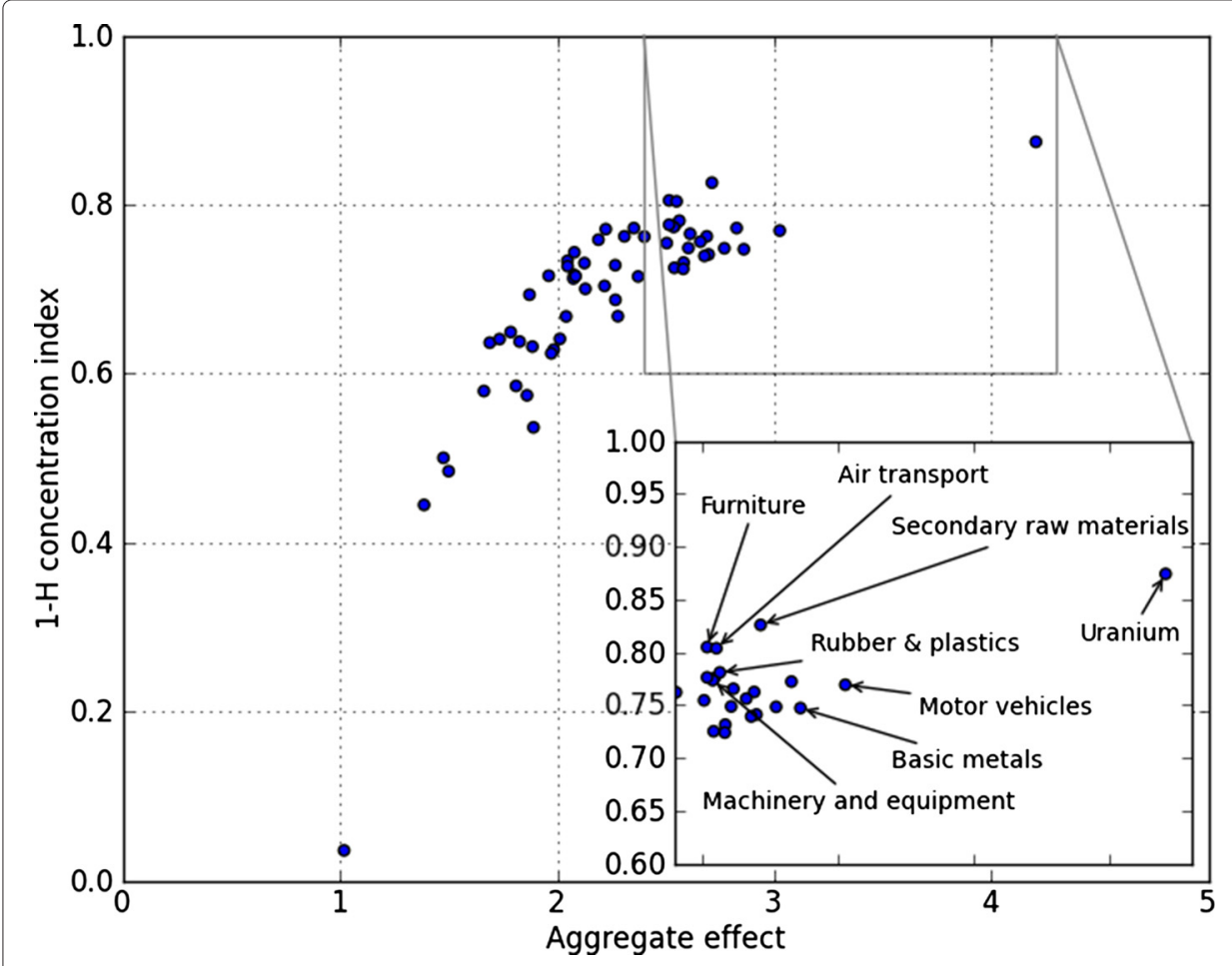

Fig. 7 Aggregate effect and diffusion of effect, European Union 


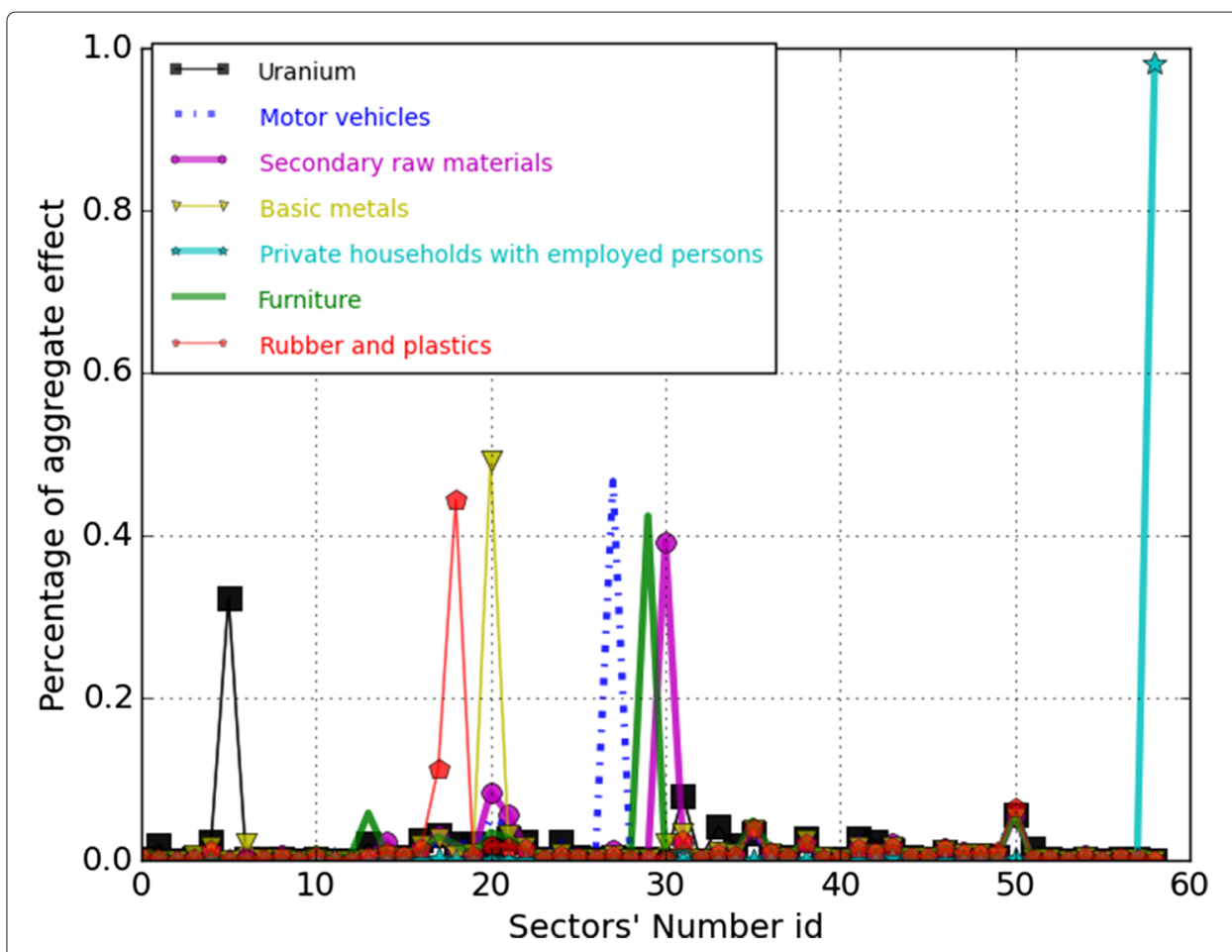

Fig. 8 Diffusion of the effect of a shock of some sectors. Peaks show a high concentration of the effect

\subsection{The most important sectors, intra-EU trade, and sector share}

The fact that the key sectors at national level are the best hubs or authorities at the European level is likely to be related to intra-EU trade relationships. ${ }^{[12]}$ For example, it is documented that the principal supplier of intermediate goods in the EU is Germany, so the spillovers that the production of these goods has on the EU's economy are important and different from other countries (Baldwin and Lopez-Gonzalez 2013).

Reports from the European Commission show the following numbers for the intra-EU trade (European Comission b). In the intra-EU trade, machinery and transport equipment represented $38.8 \%$ of total intra-EU trade, manufactured goods $16.6 \%$, chemicals $14.7 \%$, miscellaneous manufactured articles $11.13 \%$, food, drinks and tobacco $7.3 \%$, and energy products $5.8 \%$. On the other hand, the countries that accounted for most of total intra-EU trade, both dispatches and arrivals, were Germany (22\%), Netherlands (11.8 \%), France (10.7 \%), Belgium (9.3\%), Italy (8.3\%), Spain (5.1\%), and Austria (3.3\%). Other countries such as Czech Republic, Sweden, Poland, Ireland, Denmark, and Hungary accounted for less than $3 \%$ each. The strongest intra-EU trade partners for most of the countries in the EU, were Germany, France, United Kingdom, Italy, Netherlands, Belgium, and Sweden in that order of importance. Net exporters in intra-trade were Belgium, Denmark, Germany, Ireland, Hungary, Netherlands, and Slovakia.

In 2005, the Czech Republic, Germany, Hungary, Netherlands, and Slovakia had a positive trade balance in intra-EU trade, while the other countries, like France, had negative trade balance. Germany is the strongest supplier of machinery and transport equipment,

${ }^{[12]}$ Input-output tables provide information on the domestic intermediate demand for inputs whereas intra-EU trade includes exports and imports from and to European countries and final product flows. 
other manufactured goods, and raw materials to the other countries in the EU. This condition makes Germany not only a highly dependent country on its dispatches to the other countries but also a very important supplier in the EU. Machinery and equipment was one of the best authorities and hubs in Germany and is within the list of ten best hubs at the EU level. France takes the third stronger supplier, after Germany and the Netherlands, in the intra-EU trade. Most of the French intra-EU trade is food and beverages, chemicals, and machinery and transport equipment. These sectors are the most important in terms of dispatches from France to the rest of the EU, where food and beverages and chemicals were in the top ten best authorities and hubs in France. Machinery and equipment, however, was not ranked on the top ten.

Machinery and equipment has a high hub score at the EU's level, in Austria, Czech Republic, Finland, Germany, Hungary, Slovenia, and Sweden. The sector food beverages and tobacco is one of the most traded within the EU, where the strongest dispatches are from the Netherlands and France. This sector displayed high scores at the European level and high authority scores in 8 countries and a high hub score in other 16 countries of the EU. Finally, chemicals and chemical products is another sector that is strongly traded in the EU. This sector displayed high authority and hub scores at the European level and in 9 member countries: Belgium, France, Germany, Ireland, Italy, Lithuania, Netherlands, Poland, and Romania.

This gives evidence of a relation between three rankings: the most central sectors in each European country, the most central sectors in the EU regional economy, and the most intra-EU traded goods and services. In addition to finding a relation between the most important sectors and the most intra-EU traded ones, we also explored if there is a relation between our results and the sectors with the highest share in GDP in each economy and the sectors with the highest relative shares with respect to the EU. Relative shares show the share of a sector in one country with respect to the share of that sector in the entire EU, so countries with sectors that have high relative shares show an advantage in the production of the goods of that sector. ${ }^{[13]}$ Own calculations of sector shares in the EU with 2005 Eurostat data showed that the sectors with the highest shares were construction, real-estate, wholesale trade, other business services, food and beverages, chemicals, health and social work, public administration and defense, and motor vehicles. The most common sectors with the highest shares in European countries were construction, real-estate, wholesale trade, other business services, food and beverages, chemicals, health and social work, public administration, motor vehicles, and machinery and equipment. Our results are in line with European Comission (a), which shows that the sectors with the highest shares in EU GDP are other business services, health and social work, construction, public administration, financial intermediation, wholesale trade, real-estate, education, retail trade, and other services. Secondly, the sectors with the highest relative shares in most countries are crude oil and natural gas, radio television and communication equipment, office machinery and computers, wearing apparel and furs, forestry and logging, electrical machinery and apparatus, metal ores, and basic metals.

${ }^{[13]}$ We thank comments made from an anonymous reviewer who suggested to explore this venue. Relative shares are computed as follows: $r s_{c i}=\frac{\left(x_{c i} / \sum_{i} x_{c i}\right)}{\left(\sum_{c} x_{c i} / \sum_{c} \sum_{i} x_{c i}\right)}$, where $x$ is the production of sector $i$ in country $c$. 
Results showed that the sectors with the highest shares on GDP are not the top most important sectors in the EU. However, the sectors with the highest shares have above average centralities. This indicates that the most central sectors may also have a large share in the economy. This was already accounted for when we analyzed sector size. Therefore, highly central sectors are not only successful sectors in terms of production, but they are also too big to fail because a sector crisis may be diffused to other sectors and have a large impact on global GDP. Finally, we observed that the most common sectors with the highest relative shares in European countries do not correspond to the most common most central sectors with the exception of machinery and equipment and basic metals. Moreover, some of the sectors with the highest relative shares are reported as sectors that bring about a high aggregate effect on the EU economy such as office machinery and computers, and radio television and communication equipment.

The computation of measures of global centrality allows to relate several economic characteristics of sectors, such as a sectors shares, input-output linkages, and diffusion properties, thus providing useful information condensed in one ranking.

\section{Discussion}

This paper studied the productive structure of the European Union and the country members applying input-output and network analyses. With the computation of complex network measures, we revealed the complex architecture of the EU's and its constituents countries' productive structures. Their input-output networks are highly connected but not completely connected, where most of the connections are weak. By being not completely connected, it displayed an asymmetrical structure where sectors have different roles and are organized in a hierarchy where a few sectors are much more important than others.

The computation of authority and hub scores provided a ranking of the sectors according to their capacity to generate a high aggregate effect on production and a wide diffusion of the effect throughout the economy. This ranking allowed us to identify the key sectors at the national and regional level, and compare this to the intra-EU trading relationships. The best hubs and authorities in each economy are linked to the best hubs and authorities of the EU as a whole, and to the most intra-EU traded goods and services. This relation opens the possibility for a sectoral shock in one country to spread to other sectors in other countries and have an impact at the regional level. Authority and hubs scores maintain a close relationship with other measures of sectoral linkages. Nevertheless, the scores do not have themselves any interpretation in the sense of an output multiplier or an aggregated magnitude of the effect.

The analysis of the most important sectors according to network measures puts in perspective the role that the so called periphery countries, such as Hungary, may have in the economy of the EU, and, at the same time, the role of the core countries such as Germany, France, and Italy. When analyzing their productive structures, we observed, for example, that Hungary is closer to Germany, France, and the UK, while Italy is closer to Ireland. The analysis developed in this paper highlights the central, but dual, role of Germany as not only an important supplier of machinery and equipment and other intermediary goods for the European economy but also a highly dependent country on the rest of the Union, thus is also vulnerable to the health of the other economies. If a shock hits one of the most important sectors of Germany, it can have a wide impact in the whole region. 


\section{Conclusions}

These results highlighted the importance of taking into account the entire network structure, all higher order effects, and feedback effects in the diffusion process to identify the most important sectors in the economy. By focusing the analysis on the network topology, both locally and globally, we were able to detect those key sectors that can diffuse resources the widest. The existence of only a few very important nodes is a universal characteristic of all complex networks. High connectivity, along with the existence of a few authorities and hubs, allows targeted shocks to propagate from one sector to another making the economy fragile. If hubs are intentionally targeted or accidentally affected, the effects diffuse rapidly around the system. This is the reason why good hubs and authorities not only are good candidates for selective promotion but also are vulnerable points in the economy. The ranking of sectors revealed by authority and hub scores provides useful information for the policy design, especially if the government intervention aims at a high aggregate impact and wide diffusion of the resources among sectors.

One can think of different settings that can be useful to better explain the diffusion of shocks and its relation to the productive structure of an economy. The analysis of cascade effects can be explored by allowing non-linear diffusion models and a dynamic perspective, where changes in the link structure are investigated.

Competing interests

The authors declare that they have no competing interests.

Received: 27 February 2015 Accepted: 14 August 2015

Published online: 25 August 2015

References

Alatriste-Contreras MG, Fagiolo G (2014) Propagation of economic shocks in input-output networks: Across-country analysis. Technical report, ArXiv: 1401.4704

Amaral J, Dias F, Lopes J (2007) Complexity as interdependence in input-output systems. Environ Plan A 39:1170-1182

Baldwin R, Lopez-Gonzalez J (2013) Supply-chain trade: a portrait of global patterns and several testable hypothesis. NBER Working paper series Working Paper 18957. National Bureau of Economic Research, Cambridge, MA, USA

Blind JM, Murphy F (1974) On measuring economic interrelatedness. Rev Econ Stud 41:437-440

Blöchl F, Theis F, Vega-Redondo F, Fisher E (2011) Vertex centralities in input output networks reveal the structure of modern economies. Phys Rev E 83(4):046127

Bonacich P (1987) Power and centrality: A family of measures. Am J Sociol 92(5):1170-1182

Borgatti SP (2005) Centrality and network flow. Soc Networks 27(1):55-71

Chenery HB, Watanabe T (1958) Aggregate fluctuations and the network structure of intersectoral trade. Econometrica 26(4):487-521

European Comission (a) Eu industrial structure 2009: Performance and competitiveness. ISSN:1831-3043

European Comission (b) External and intra-eu trade: a statistical yearbook data 1958-2010. Technical report, Eurostat, Luxembourg

Dietzenbacher E (1992) The measurement of interindustry linkages: Key sectors in the Netherlands. Econ Model 9(4):419-437

Dietzenbacher E, Romero I (2007) Production chains in an interregional framework: Identification by means of average propagation lengths. Int Reg Sci Rev 30(4):362-383

Dietzenbacher E, van der Linden JA (1997) Sectoral and spatial linkages in the ec production structure. J Reg Sci 37(2):235-257

Garcia-Muniz AS, Morillas A, Ramos C (2008) Key sectors: A new proposal from network theory. Reg Stud 42:1013-1030 Herfindahl OC (1950) Concentration in the US Steel Industry. PhD thesis, Columbia University, NY, NY, USA

Hirschman AO (1958) Strategy of Economic Development. Yale University Press, New Haven, CT, USA

Humavindu M, Stage J (2013) Key sectors of the Namibian economy. Journal of Economic Structures 2(1):1-15

Jones LP (1975) The measurement of Hirschmanian linkages. Q J Econ 90(20):323-333

Kleinberg JM (1999) Authoritative sources in a hyperlinked environment. J ACM 46(5):604-632

Langville AN, Meyer CD (2005) A survey of eigenvector methods for web information retrieval. SIAM Rev 47(1):135-161. ISSN 0036-1445

Leontief W (1949) Structural matrices of national economies. Econometrica 17:273-282

McGilvray J (1977) Structure, System and Economic Policy, chapter Linkages, Key Sectors, and Development Strategy. Cambridge University Press, NY, NY, USA

McNerney J, Fath BD, Silverberg G (2012) Network structure of inter-industry flows. Phys A: Stat Mech Appl 392(24):6427-6441 
Miller RE, Blair PD (2009) Input-Output Analysis. Foundations and Extensions. Second edn. Cambridge University Press, $N Y, N Y, U S A$

Newman MEJ (2010) Networks: An Introduction. Oxford University Press, NY, NY, USA

Rasmussen N (1956) Studies in Intersectoral Relations. North-Holland Publishing Co., Amsterdam

Reyes FA (2002) Structural transformations and important coefficients in the north american economies. Econ Syst Res 14(3):257-273

Slater P (1978) The network structure of the united states input-output table. Empir Econ 3(1):49-70

Temurshoev U, Oosterhaven J (2010) On input-output linkage measures. International Input-Output Association Working papers in Input-Output Economics. IIOA, Vienna, Austria

Thakur SK (2011) Fundamental economic structure and structural change in regional economies: A methodological approach. Region et Development 33:9-38

Xu M, Allendy B, Crittenden J (2011) Interconnectedness and resilience of the U.S. economy. Adv Complex Syst 14(5):649-672

Submit your manuscript to a SpringerOpen ${ }^{\circ}$ journal and benefit from:

- Convenient online submission

- Rigorous peer review

- Immediate publication on acceptance

- Open access: articles freely available online

- High visibility within the field

Retaining the copyright to your article

Submit your next manuscript at $\boldsymbol{\triangleright}$ springeropen.com 